\title{
Interleukin-10 transfection and the donor lung-A still-evolving story
}

\author{
John H. Dark, FRCS
}

\author{
From the Institute of Cellular Medicine, Faculty of Medical Sciences, Newcastle University, Newcastle upon \\ Tyne, United Kingdom. \\ Disclosures: Author has nothing to disclose with regard to commercial support. \\ Received for publication June 5, 2018; revisions received June 5, 2018; accepted for publication June 5, 2018. \\ Address for reprints: John H. Dark, FRCS, Institute of Cellular Medicine, Faculty of Medical Sciences, Newcastle \\ University, Newcastle upon Tyne NE2 4HH, United Kingdom (E-mail: john.dark@ncl.ac.uk). \\ J Thorac Cardiovasc Surg 2018;156:1303-4 \\ $0022-5223 / \$ 36.00$ \\ Copyright $(2018$ by The American Association for Thoracic Surgery \\ https://doi.org/10.1016/j.jtcvs.2018.06.009
}

Pulmonary transplantation is a struggle. The donor lung is vulnerable to a range of insults - aspiration, transfusion, ventilation, as well as the sequelae of brainstem death. This last insult brings inflammatory upregulation and profound effects on early graft performance and a wellcharacterized link to late attrition.

The impact on our day-to-day clinical practice is depressingly clear. With concerns over damaged organs, we use little more than $20 \%$ of potential donor lungs, and patients die on our waiting lists. Chronic graft failure, now all characterized together as chronic lung allograft dysfunction, remains the single most frustrating feature of our specialty. Median survival for the whole population of lung transplant recipients is stuck at around 5 or 6 years; it has changed little over the past 2 decades. $^{2}$

There are some potential ways out of this predicament; interleukin-10 (IL-10) is a pleiotropic anti-inflammatory cytokine and might just have a key role. Raised expression is beneficial in the early, acutely injured transplant lung. In addition, stable lung transplant recipients appear to have greater levels than those developing as chronic lung allograft dysfunction.

There is a long story of attempts to increase IL-10 expression in the lung, using a viral vector carrying the relevant IL-10 gene, going back as far as 2001. The Toronto group, leaders in this field, have shown early benefit in rat and pig lung transplant models. Their seminal Science paper showing the same advantage in human lungs using adenoviral transfection and ex vivo lung perfusion dates back to 2007.5

This latest paper $^{6}$ concentrates on longer-term effects and uses a lentiviral, not adenoviral, vector. The authors demonstrate that giving the viral carrier into the airway, both to the donor lung at the time of transplant and later, to the lung in the recipient, leads to persistent expression and has demonstrable benefits. There was lower acute rejection at 28 days (although not at 7 days) and probably less fibrosis at the later stage. By extrapolating from some complex chronic rejection.

\section{References}

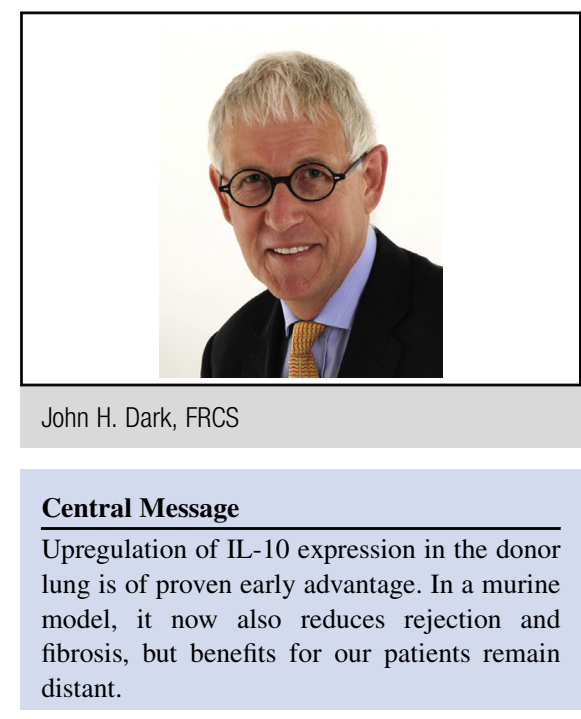

See Article page 1305.

lymphocyte pathways, it seems that there was less late immune activity-equivalent, the authors claim, to less

This work is an important step, but just a step, to the end result of clinical application. It raises as many questions as it answers. The model, a minor-mismatched mouse transplant, although integral to the gradual development of the approach, is still a long way from clinical lung transplantation. Vector delivery is via the airway, feasible with the tiny dimensions of the mouse lung, but perhaps difficult to reproduce on a human scale. What has happened to the ex vivo lung perfusion delivery, so appealing in exposing only the donor lung, not the whole host, to any downsides of viral transfection?

This is a beautifully performed, elegant set of experiments, with some real and well-argued insights into the mechanisms at the level of the effector immune cells. But, most frustratingly, the authors, for all their background of leading clinical advances, give us no feel for where it is all going. We look toward the next step.

1. Whitson BA, Prekker ME, Herrington CS, Whelan TP, Radosevich DM, Hertz MI et al. Primary graft dysfunction and long term pulmonary function after lung transplantation. J Heart Lung Transplant. 2007;26:1004-11.

2. Yusen RD, Edwards LB, Kucheryavaya AY, Benden C, Dipchand AI, Dobbels F, et al. The registry of the International Society for Heart and Lung Transplantation: thirty-first adult lung and heart-lung transplant report-2014; focus theme: retransplantation. J Heart Lung Transplant. 2014;33:1009-24. 
3. Bianco AM, Solari N, Miserere S, Pellegrini C, Vitulo P, Pozzi E, et al. The frequency of interleukin-10- and interleukin-5-secreting CD4 T cells correlates to tolerance of transplanted lung. Transplant Proc. 2005;37:2255-6.

4. Fischer S, Liu M, MacLean AA, de Perrot M, Ho M, Cardella JA, et al. In vivo transtracheal adenovirus-mediated transfer of human interleukin-10 gene to donor lungs ameliorates ischemia- reperfusion injury and improves early posttransplant graft function in the rat. Hum Gene Ther. 2001;12:1513-26.
5. Cypel M, Liu M, Rubacha M, Yeung JC, Hirayama S, Anraku M, et al. Functional repair of human donor lungs by IL-10 gene therapy. Sci Transl Med. 2009; $1: 4 \mathrm{ra} 9$

6. Oishi H, Juvet SC, Martinu T, Sato M, Medin JA, Liu M, et al. A novel combined ex vivo and in vivo lentiviral interleukin-10 gene delivery strategy at the time of transplantation decreases chronic lung allograft rejection in mice. $J$ Thorac Cardiovasc Surg. 2018;156:1305-15. 